\title{
Public Open Space as a Contribution to Urban Development in Small Slovenian Cities
}

\author{
Petra Vertelj Nared \\ Alma Zavodnik Lamovšek
}

Petra Vertelj Nared, Ljubljanski urbanistični zavod, d.d., Slovenia (petra.vertelj-nared@luz.si) Alma Zavodnik Lamovšek, University of Ljubljana, Faculty of Civil and Geodetic Engineering, Chair of Spatial Planning, Slovenia (alma.zavodnik@fgg.uni-lj.si)

\begin{abstract}
The article focuses on public open space (POS) in small Slovenian cities ${ }^{5}$. It highlights the importance of planning and designing high-quality, diverse POSs, which contribute to the quality of life and urban development in cities. POS is seen as a key physical element of a city and is defined as a non-built urban space that is, under equal terms, accessible to all. The article focuses on both green areas and civic space. Results derive from a physical analysis and survey conducted during research for a doctoral dissertation. Ten small Slovenian cities are selected, where detailed physical analysis and surveys were carried out. Designing highquality POS for everyday activities is highlighted. The results show that the inhabitants most frequently use POS when going about their everyday business. The article highlights the importance of designing various types of POS for urban development of cities.
\end{abstract}

Keywords: public open space, quality of life, urban development, small cities, use of public open space, spatial planning

\section{Introduction}

The article highlights public open space (POS) as one of the key elements for the quality of life and as a contribution to urban development. Urban development is the development of cities, and for the purposes of this study we understand it to mean designing the physical conditions of a city that contribute to the quality of life. POS with its various functions social, structural, economic, as well as ecological - importantly contributes to sustainable urban development according to the urban development agendas for improving cities (Urban 21 Conference, 2000; Leipzig charter ..., 2007). The aims of urban development in general are to improve the quality of life in cities, where high-quality POS with green and civic areas plays an important role.

POS is seen as closely related to the green infrastructure of the city. POS consists of green space and of civic space (Urban Open and Green Space Typology, 2002; Planning and Open Space, 2008). Beside buildings, it is one of the key physical elements of the city. Various authors define POS as a place for living, place of society, a place of public life, a place of urbanity (for example: Low and Smith, 2006; Kos, 2008; Madanipour, 2012). We defined POS as a city's non-built space that is accessible to the public (ZGO-1, 2002; Vertelj Nared, 2014). Even though the quality of life usually has to do with environmental indicators or housing standards (European Green City Index, 2010; Sendi, 2013) and POS is usually not highlighted as a particular category (see Mercer, 2010), POS has lately been recognized as an essential spatial structure, which increases a city's quality of life (Frick and Hoefert, 1986; Beck, 2009; Quality of life ..., 2004; Urban Audit, 2011). Several studies show that POS has an essential influence on people's well-being and health conditions (Jackson, 2003; Maas et al., 2006; Sugiyama and Ward Thompson, 2007; Paquet et al., 2013).

\footnotetext{
5 This article is based on research conducted for a doctoral dissertation (Vertelj Nared, 2014).
} 
In this article we focus on POS and its use in small cities. We focus on user experiences. For this reason, the main research questions address the improvement of the quality of life in small cities, taking the example of ten small Slovenian cities ${ }^{6}$. As user experience is of great importance in further urban development planning (Quality of life .., 2004; Kos, 2010; Cerar, 2014; Bratina Jurkovič, 2014), we are interested in: (a) what types of POS city dwellers most frequently use, (b) what types of POS residents recognize as particularly important, and (c) what types of POS should never be lacking in any city, including small ones. The results discussed below derive from research conducted in ten small Slovenian cities (Vertelj Nared, 2014).

The article also focuses on how POS is integrated into local planning. The importance of good local spatial plans is broadly recognized as a key element in improving physical space and the quality of life (Thematic strategy on urban environment, 2006). The European Parliament has stressed the importance of defining appropriate amounts of green areas in local spatial plans and maintaining natural environments in urban development so residents retain contact with natural areas (ibid.). The Leipzig Charter on Sustainable European Cities (2007) states that one of the measures for strengthening the competitiveness of European cities is to create and deliver high-quality public spaces that have a significant influence on the living conditions of the urban population. The requirements for improving quality of living space are also stated at the national level, also in Slovenia. For example, The Spatial Development Strategy of Slovenia (SDSP, 2004), a basic national document on spatial development, establishes requirements for improving the quality of life in settlements in terms of wellbeing, economic efficiency and environmental suitability and sustainability. This means an important obligation for all participants in the spatial planning process to create adequate conditions for the sustainable development of human settlements in local spatial plans and projects. Although the recommendations or demands of general agendas, declarations and documents provide a basis for improving the quality of a living space, the problem of the quality of a POS is recognized in small Slovenian cities, where the core for improvements in spatial development lies in local plans and projects. It is therefore essential to focus on the local level.

On the basis of the above research questions, we define the following hypothesis: for the everyday life and quality of life of residents in small cities, the various types of public open space (both green areas and civic space) is of great importance.

\section{Starting points and theoretical background \\ Green infrastructure, public open space and the quality of life}

The definition of green infrastructure as "a strategically planned network of natural and semi-natural areas with other environmental features designed and managed to deliver a wide range of ecosystem services" (Green Infrastructure..., 2013: 3) has various broader meanings and roles. In general, we can see green infrastructure as areas, elements, or connections in open space. An inevitable part of the green system is both public and private space. As open space is composed of both green space and civic space, the meaning of open space for urban development is wider than the green system.

Besides structural, economic, and ecological functions, public space also performs significant social and symbolic functions in the city, and is therefore social and symbolic space. Carr et al. (1992: 3) claim that public space can help satisfy people's needs, shape, define, and protect significant human rights, and convey special cultural meanings. Madanipour (2012: 141) believes that the relationship between people and an urban environment is a significant factor in determining the nature of a public space.

\footnotetext{
${ }^{6}$ The term "small city" is used in this article, rather than the term "small town", in order to stress the functional importance of selected small cities, as they are micro-regional centres and/or municipal centres (Table 1).
} 
The importance of preserving and maintaining a city's open space as an unbuilt spatial structure is of broader interest and concerns several values. Only in recent decades has the importance of POS in connection with economic values been recognized (Luttik, 2000). Furthermore, environmental values are reflected in POS' contribution to a city's structure, by reducing the use of private cars, reducing noise, and improving air quality, along with caring for biodiversity, water, and soil, and providing retention space (Planning and Open Space, 2008). But the role of POS is highly complex in modern cities, and we should study it not only in terms of cities' various spatial and ecological functions and physical-geographical characteristics, but especially in terms of POS contribution to complex social processes that shape urban contexts. The positive influence of POS on social values in cities are to be found for example in encouraging interaction among users, residents' identification with cities, offering the possibility for caring for the local environment, reducing the possibility of crime and fear of crime, offering opportunities for sport and recreation, and encouraging active and healthy lifestyles, which contribute to the overall health of a population (Planning and Open Space, 2008).

The concept of quality of life in connection with improving the built environment in cities is not new (see Mumford, 1969), but just recently the importance and the role of POS in the quality of life and the improvements it brings to physical and mental health and well-being is widely approved (Healthy Open Spaces, 2010; Richardson \& Mitchell, 2010; Ward Thompson \& Aspinall, 2011; Ward Thompson et al., 2012; Dinnie et al., 2013). It has been shown (Vertelj Nared, 2014) that well-managed POS contributes significantly to better living conditions and urban development in small cities. It has been demonstrated that well-managed and diverse public open space contributes considerably to its use and residents' satisfaction there (ibid.). In the light of the statements presented about the different roles of public space, we focus on residents' use of and satisfaction with POS as indicators of the quality of life.

\section{Small cities and the role of local spatial planning: a Slovenian case study}

Only 156 of 6,000 settlements in Slovenia are defined as towns, cities, and other urban settlements (Pavlin et al., 2003), in which less than half of the country's population reside (SURS, 2010). According to Zavodnik Lamovšek et al. (2008), urban structure in Slovenia comprises one big city (Ljubljana, the capital), 11 medium-sized cities and 82 small cities (towns). The network of medium-sized and small cities is a key framework for sustainable polycentric spatial (urban) development in Slovenia (SDSP, 2004). Small cities have recently received more attention from researchers worldwide (Mostafavi \& Doherty, 2010; Bell \& Jayne, 2006), even though they are defined differently in different countries (ESPON, 2006). For example, a small city with more than 50,000 inhabitants on the European scale would mean a medium-sized city in Slovenia. To be precise, in 2013 more than half of Slovenian cities (54 out of 93) had fewer than 5,000 inhabitants (SURS, 2013) and only the capital city Ljubljana is defined as a big city with around 280,000 inhabitants (ibid.). It is therefore logical to focus on small cities when analyzing the POS in connection to the quality of life.

The key European document on the protection, management, and planning of European landscapes, including open space in cities, is the European Landscape Convention (2003), which is implemented differently in different European countries (Stiles, 2009). Spatial development is a matter for each individual European country. The importance of providing adequate POS, both green and civic space, therefore relies on national and local spatial planning legislation. Spatial Order of Slovenia (SOS, 2004) is the Slovenian national framework for POS spatial planning at the local level, but implementation is the right and obligation of local authorities. Quantitative and qualitative POS requirements are specified by municipal spatial plans, detailed municipal spatial plans, and design projects. Municipal spatial plans are key local strategic and implementing documents. At the implementation 
level, they define land use and detailed spatial requirements. The new generation of Slovenian municipal spatial plans adopted after 2007 show that requirements still tend to be quantitative (normative) rather than qualitative. Currently, requirements only define green space (for example the amount of a green space or the number of trees on a building plot) but not POS as a physical (spatial) element of built up structures in cities. The question therefore remains as to whether municipal plans can ensure better, high-quality POS that contributes to the quality of life in cities.

\section{Methods}

It is firstly important to define how POS contributes to the quality of life and how this contribution can be measured. We are interested in the quality of life, specifically the conditions of POS and people's satisfaction with them. The starting point is that the definition of quality is always the result of an evaluation process of what is good, what is better, and what is worse. Starting with Fromm's (2002) definition, that "good" or "bad" refers to the usefulness for the user, a thing is called "good" if it is good for the user. In our research we therefore focus on the qualitative aspect, satisfaction with and usefulness of POS. We accordingly used qualitative indicators and methods rather than objective measurements of the quality of life based on other quantitative data (such as health status of the population, unpolluted air, unnoisy environment, etc). The research therefore deals mainly with physical (spatial) and social aspects of the quality of life, rather than economic or environmental aspects. Qualitative research methods (Vertelj Nared, 2014) for exploring the relation between physical characteristics, people's satisfaction with a space and the existing or planned land use in spatial plans have been used.

In the first step, small Slovenian cities were selected. As mentioned before, small cities are the most numerous and for polycentric development the most important (Zavodnik Lamovšek et al., 2008), but in terms of POS in Slovenia they are a poorly researched group of settlements.

The basic group of small Slovenian cities is taken from a previous study entitled "Small and Medium-Size Towns as the Basis of Polycentric Urban Development" (Zavodnik Lamovšek et al., 2008). According to that study, small cities make up a heterogeneous group that differ in function as well as in size and number of inhabitants (from fewer than 1,500 to more than 25,000 per city). In order to limit the chosen Slovenian cities to a homogenous group comparable in function and size but still different in morphological structure and location, we identified additional criteria and indicators for their selection (Table 1):

- Cities are determined by population with cities with between 3,000 and 5,000 inhabitants being selected, also due to the fact that in Slovenia this is the largest group of cities / towns.

- Cities are located in different statistical regions.

- Cities have the same level of functions, which means the same role in polycentric urban system in Slovenia.

- Cities are compact settlements with a population density of over 1000 inhab./ $/ \mathrm{km}^{2}$.

Table 1: Criteria and indicators used for selection of small cities.

\begin{tabular}{|c|c|c|c|}
\hline Criteria & Indicator & Chosen value & $\begin{array}{l}\text { Result: number } \\
\text { of cities }\end{array}$ \\
\hline Formal & Number of inhabitants & $3000-5000$ & 29 \\
\hline Location in & Located in different & Name of the region (e.g. & \\
\hline Slovenia & Slovenian regions & $\begin{array}{l}\text { Gorenjska, Goriška, } \\
\text { Primorska, Notranjska) }\end{array}$ & 10 selected cities \\
\hline Functional & Same level of functions & Micro-regional centres & \\
\hline
\end{tabular}


and the same role in polycentric urban system in Slovenia Morphological Compact settlement and/or municipal centres

Population density is

higher than 1000

inhab. $/ \mathrm{km}^{2}$.

Out of 29 small cities with 3,000 - 5,000 inhabitants, ten were selected for detailed research (Figure 1).

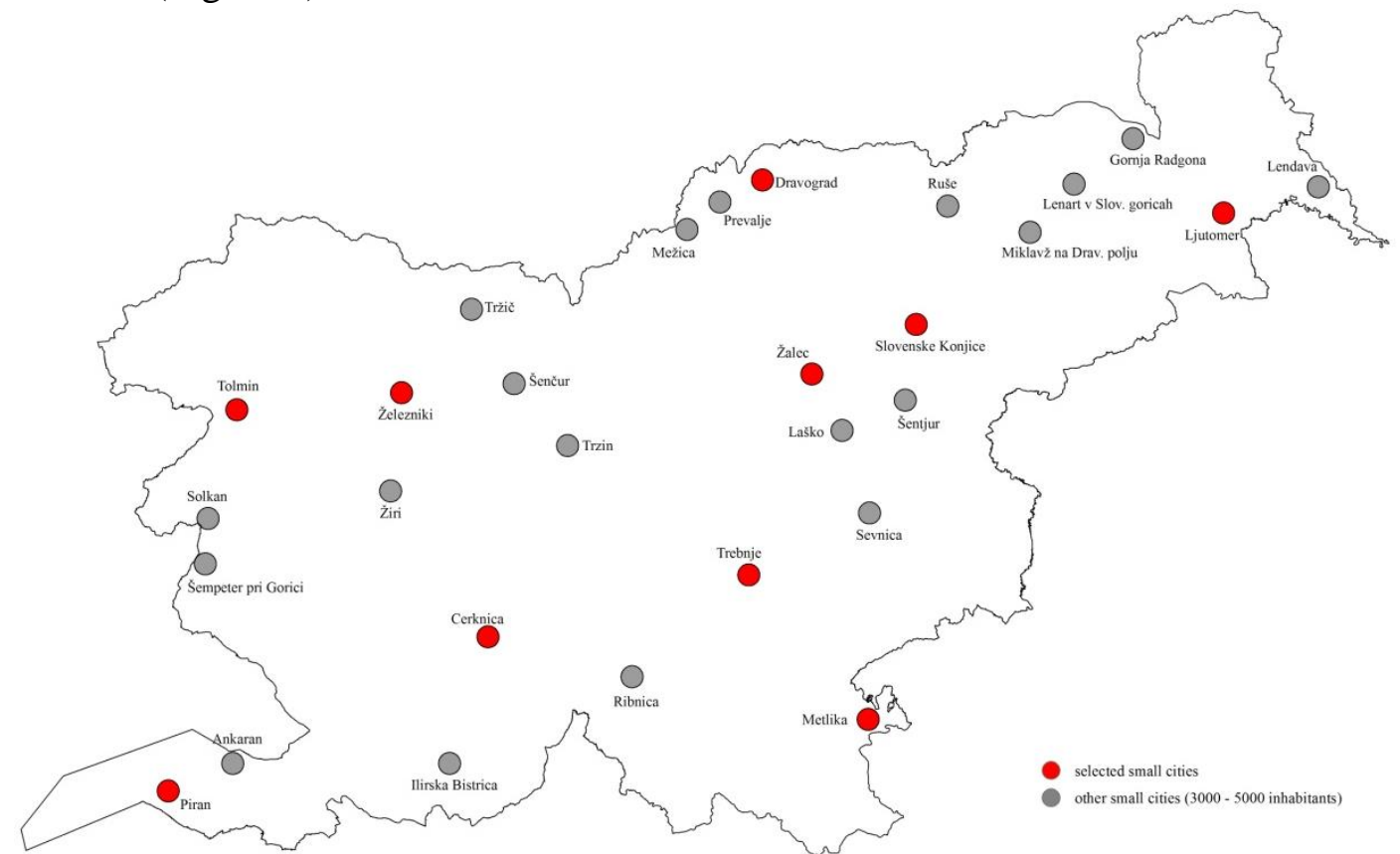

Figure 1: Small cities selected for research in Slovenia (source: Zavodnik Lamovšek et al., 2008).

It the second step, physical characteristics were analysed in ten small Slovenian cities. Spatial analysis includes data on the location of POS in the city scale, types of POS, and quantity of POS in each city. Since there are no such data available at the national level, all data have been acquired for research purposes, both from other accessible spatial data and through field work. The types of POS were defined as follows: (a) city park, (b) city square, (c) children's playground, (d) sport playground, (e) school playground, (f) cemetery, (g) allotments, (h) water and waterfronts, (i) open space in front of buildings of social significance, $(\mathrm{j})$ streets, and $(\mathrm{k})$ forest and agricultural land.

In the third step, a survey questionnaire about the level of resident satisfaction with living conditions in cities was designed. Sending the questionnaire by mail was selected as most appropriate way of gaining people's opinions. The advantages of a mail survey are that it reaches the widest range of people; it allows the anonymity of respondents and freedom in choosing when to complete the questionnaire. In addition, a mail survey can be longer in content, with pictures and maps attached on which residents can enter their observation themselves. Despite the subjectivity, this method allows comparison of results based on shaped quantitative criteria. The questionnaire contained 34 questions, some addressing the usability of and satisfaction with various types of POS, as well as the quality of life in relation to POS. 4772 questionnaires were sent to inhabitants aged 18 years and over in ten cities. The questionnaire was therefore received by between $11 \%$ and $13 \%$ of the population in the cities 
under study. Data was collected from the beginning of June to the beginning of September 2012. The response rate was $26.7 \%$ (1272 responses of 4772 questionnaires despatched).

\section{Results}

The selected cities differ in scale and morphological urban structure (Figure 2), which is determined primarily by the natural geographical characteristics in the region, the origins of the settlement, and the historical urban development of each city.

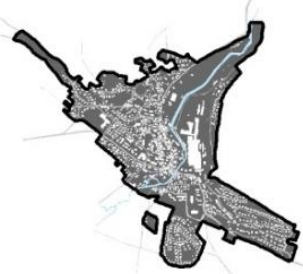

Cerknica

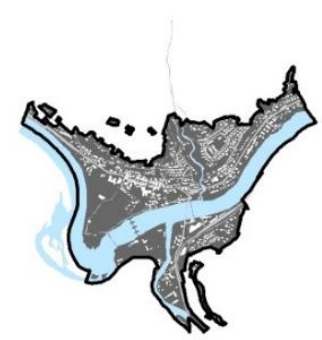

Dravograd

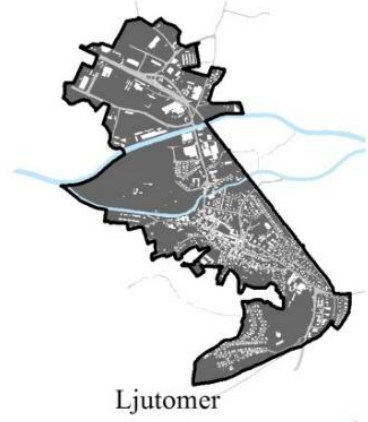

Ljutomer

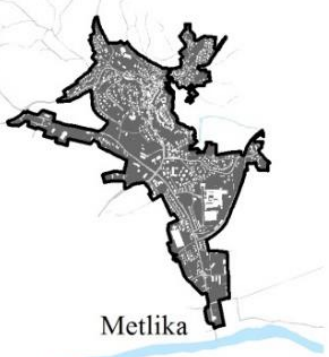

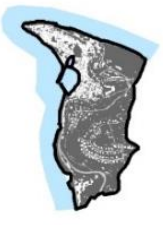

Piran

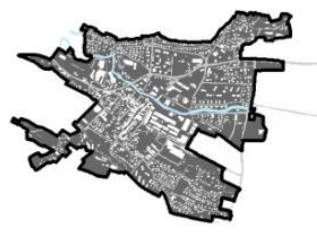

Slovenske Konjice

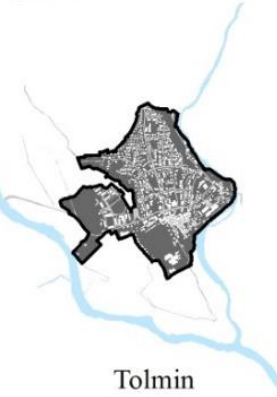

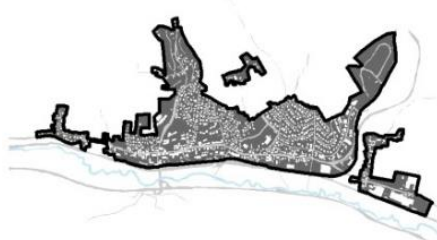

Trebnje

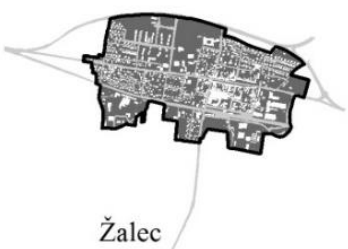

Žalec

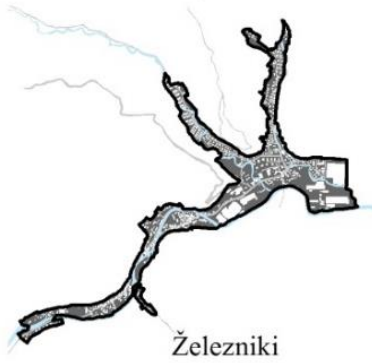

Železniki

Figure 2: Morphological characteristics of small cities under study (source: Vertelj Nared, 2014).

Ljutomer and Žalec are situated in a mainly flat area and are surrounded by agricultural land. Piran is the only coastal settlement. Others lie mainly on hilly terrain or at the foot of hills.

Cerknica is in the central part of Slovenia, Notranjska, to the north of Cerknica Lake and below Slivnica hill. Dravograd lies in Koroška in northern Slovenia, and is situated on the rugged terraces of the Drava river bed. Ljutomer is a regional center of Prlekija in the northeast, a flat part of the country. Metlika is a border city in Bela krajina in southeastern Slovenia, where the plain along the Kolpa River meets the hills. Piran is an old coastal town in Primorska on the Piran peninsula, with narrow streets and dense housing from medieval times. Slovenske Konjice lies to the east in Štajerska region amid vinyards on the Dravinja River. Tolmin is situated on a triangular terrace at the confluence of the Soča and Tolminka rivers in northwestern part of the country. Trebnje is an elongated city in the eastern Dolenjska region on the route from Ljubljana to Novo mesto. Žalec is situated on a plain in 
the middle of the lower Savinja River valley in central-eastern Slovenia surrounded by agricultural land. Železniki is an elongated city in the hilly Gorenjska region, situated in the narrow valley of the Selška Sora River.

The cities differ in size and population density, the most populous being Slovenske Konjice and Žalec (Table 2).

Table 2: Number of inhabitants and location of selected small cities in Slovenia.

\begin{tabular}{lll}
\hline Selected city & $\begin{array}{l}\text { Population } \\
\text { (SURS, 2012) }\end{array}$ & $\begin{array}{l}\text { Location in Slovenia } \\
\text { (Name of tregion) }\end{array}$ \\
\hline Cerknica & 3946 & Notranjska \\
Dravograd & 3330 & Koroška \\
Ljutomer & 3453 & Prlekija \\
Metlika & 3330 & Bela krajina \\
Piran & 4092 & Primorska \\
Slovenske Konjice & 4891 & Stajerska \\
Tolmin & 3525 & Goriška and Posočje \\
Trebnje & 3478 & Dolenjska \\
Žalec & 4913 & Štajerska \\
Železniki & 3069 & Gorenjska \\
\hline
\end{tabular}

\section{Public open space}

The physical (spatial) analysis shows that the cities are variously endowed with the different types of POS (Figure 3). City squares, school and sports playgrounds, and cemeteries are present in all cities, although to varying degrees and of varying quality. School and sports playgrounds usually refer to the same area. But there are important differences in the presence of POS, especially for the following types: city parks, children's playgrounds, and the central town square. Indeed, not all places have a city park or a public-access children's playground.

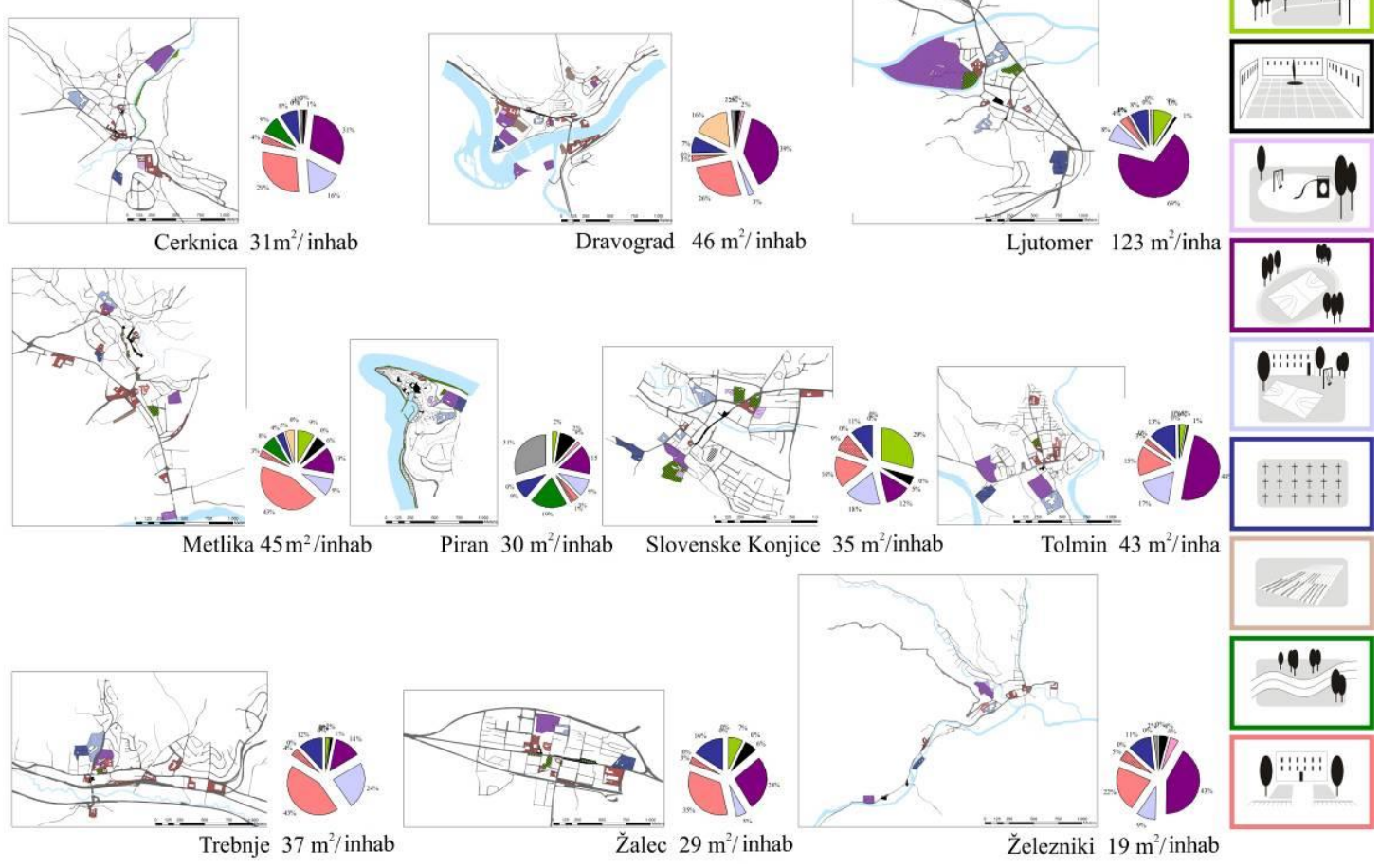

Figure 3: Spatial analysis of public open space by type and size (source: Vertelj Nared, 2014). 
There is, for example, no city park in three of the ten cities (Cerknica, Dravograd, Železniki), while in others park quality differs. The park is often part of another spatial arrangement, such as a town square (for example in Metlika); only rarely it is an important and inherent spatial structure of the city (for example in Ljutomer or Slovenske Konjice, Figure 4).

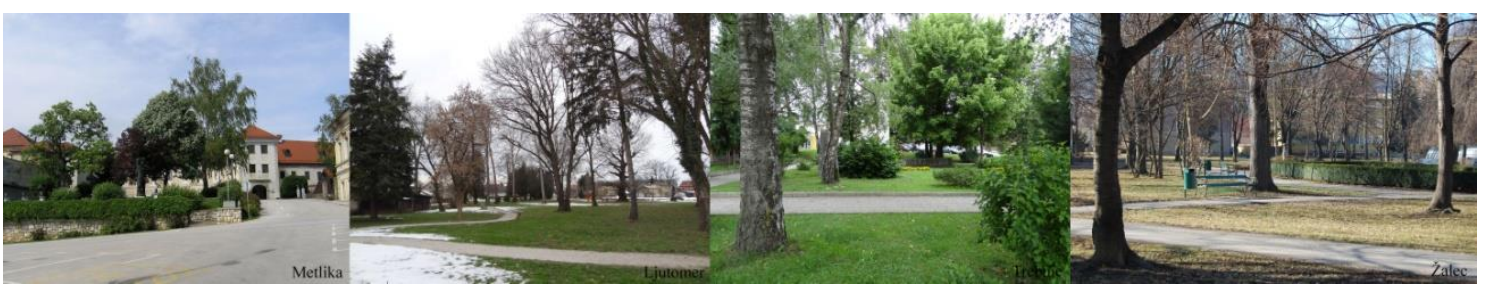

Figure 4: City parks in various small Slovenian cities (photo: Petra Vertelj Nared).

The town square is also very different from one place to another. It can for example be the city's central open space (as in Piran or Ljutomer), it can be the city's former main street (in Slovenske Konjice), or it can also be part of a major traffic route through the city (in Dravograd and Trebnje). The important characteristic of a square in small cities is whether it is open only to pedestrians or also to motorised traffic. Most are accessible to both (for example Metlika, Figure 5).

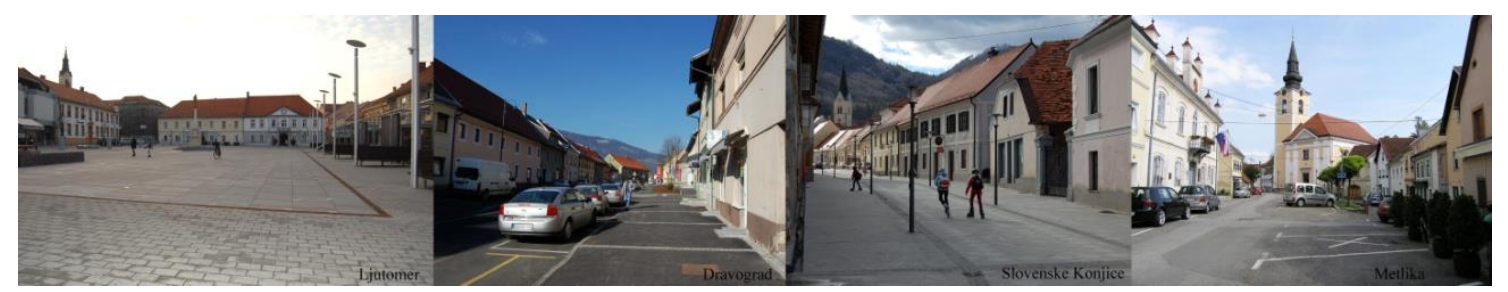

Figure 5: Town squares in small Slovenian cities (photo: Petra Vertelj Nared).

The most important types of POS are often situated in the vicinity of buildings of special social importance. Playgrounds, in particular, are often located near elementary schools. On the other hand, POS is lacking in other parts of the city. POS is abset especially in the newer urban areas and housing areas, particularly those with single-family housing, which even want for children's playgrounds. Exceptions are urbanised areas of multi-family housing, which are usually provided with new children's and sports playgrounds.

The cities under study also differ in the provision of sidewalks, bicycle paths, and treelined avenues. Bicycle paths and tree-lined avenues, in particularly are the exception rather than the rule, even if they are to be found in newly designed urban areas or streets (Figure 6).

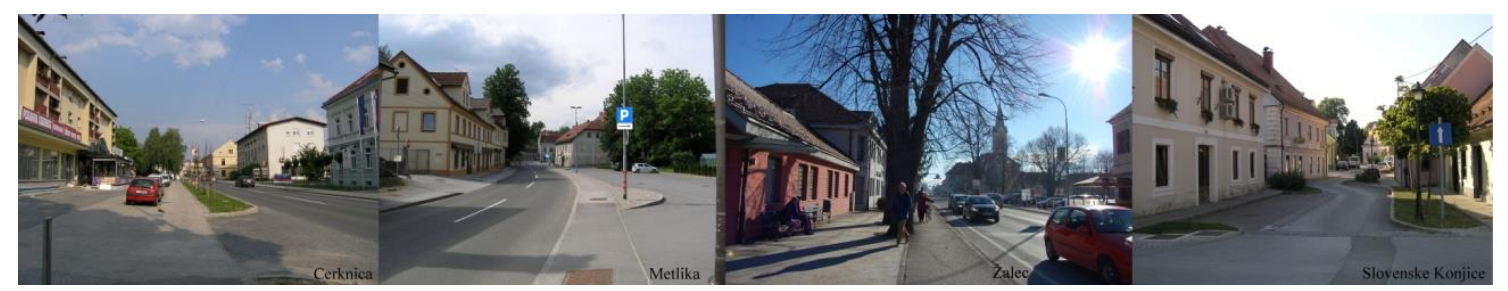

Figure 6: Streets in small Slovenian cities (photo: Petra Vertelj Nared).

Beside the different types of POS, the environs of small cities constitute a special spatial structure. They vary depending on the natural-geographical characteristics of the particular city (e.g. slopes are dominated by forests while flat areas are dominated by agricultural land), 
but the majority of cities are located by forests. Proximity to nature is common to the majority of Slovenian settlements in general.

\section{Survey results on public open space and the quality of life}

The survey results show the top three topics ${ }^{7}$ that respondents recognise as contributing to the quality of life: "a healthy and clean living environment" $(68.6 \%)$, "accessibility of social and public services" (68.1\%) and "good infrastructure" $(57.7 \%)$. Fourth is "coexistence with people who respect and accept each other" $(34.8 \%)$ and fifth "possibilities for recreation and leisure-time activities" (27.6\%). According to the survey results, respondents associate the quality of life mostly with the physical characteristics of the environment, which preferably should be well-maintained, clean, and accessible.

For the quality of life, the physical environment therefore is of great importance. To gain deeper insight into the question of how important POS is for everyday life in small Slovenian cities, we asked inhabitants what they usually do in POS, and what types of POS they most frequently use.

Most frequently, respondents use POS to go about their daily business (86\%), rather than for other leisure or else activities (Figure 7). The functional, everyday space is therefore of great importance, also when considering how to improve the physical environment to enhance the quality of life in these cities.

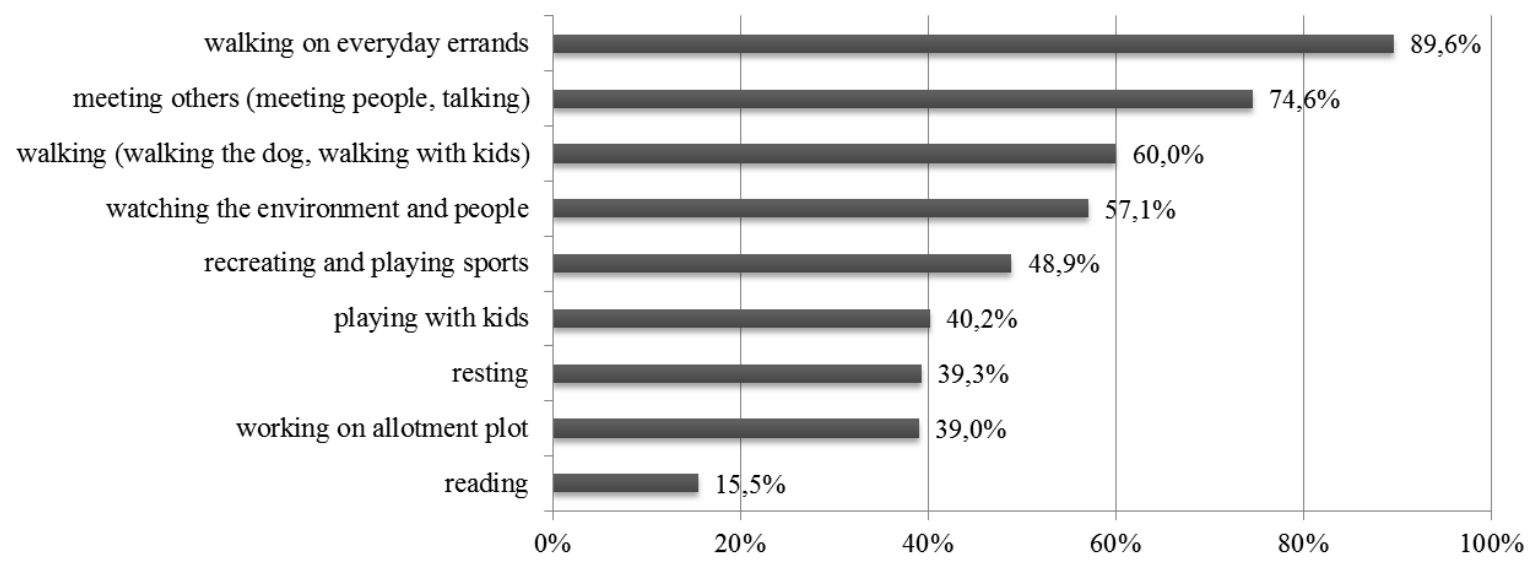

Figure 7: Results to the question what you usually do in public open space (source: Vertelj Nared, 2014).

According to Gehl's (2006) definition of groups of activities in POS ("necessary activities", "optional, recreational activities", and "social activities"), the results show that necessary activities come first (going about everyday business), with social activities (gathering, talking, meeting each other) and optional, recreational activities (recreating, watching) coming only second and third. These findings are confirmed by the answers to the question, "how often do you use different types of POS in your city?" as they show that the most frequently used space is that before the home and streets (Figure 8).

\footnotetext{
${ }^{7}$ They had to choose three among seven things: (1) good infrastructure; short distance between home and work; (2) possibilities for recreation and other leisure-time activities; (3) proximity and good maintenance of public open space; (4) a healthy and clean environment; (5) coexistence with people who respect and accept each other; (6) the sense of belonging to your place of residence; (7) accessible services (health care, child care etc.).
} 


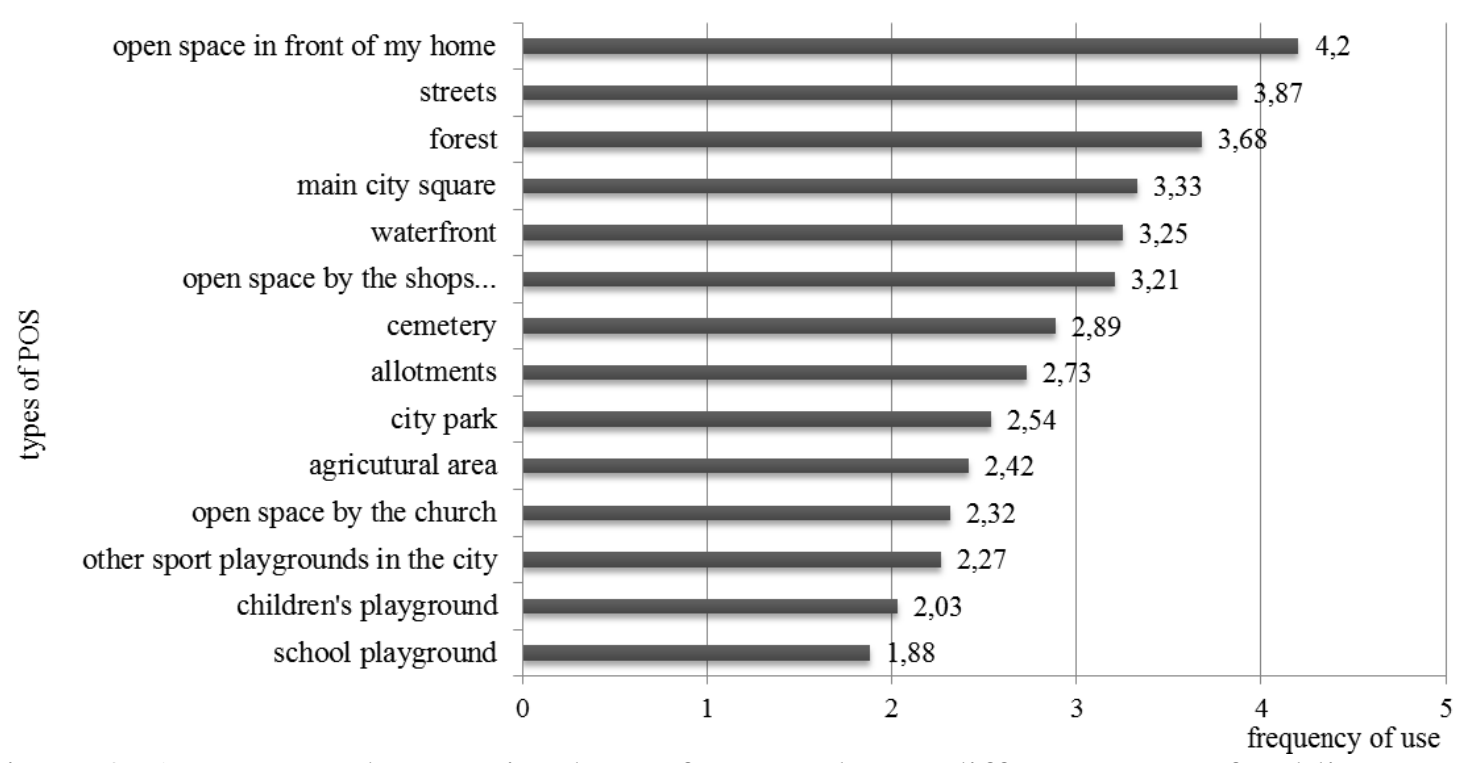

Figure 8: Answers to the question how often people use different types of public open space in their city (ranging from 1 to 5, where 1 means less often and 5 means most often) (source: Vertelj Nared, 2014).

On the other hand, results to the question of the type of POS respondents are most likely to spend their free time show that only $11.2 \%$ prefer the street, most preferring forest $(29.0 \%)$ or areas in front of their homes (27.4\%) (Figure 9). A preference for the open space in front of the home is not surprising, since a majority of respondents live in single-family buildings (68.7\%), while only just under a third live in multi-family housing (31.3\%). In this regard, results reflect the general and much-discussed "un-urbanity" of Slovenes (Kos, 2007).

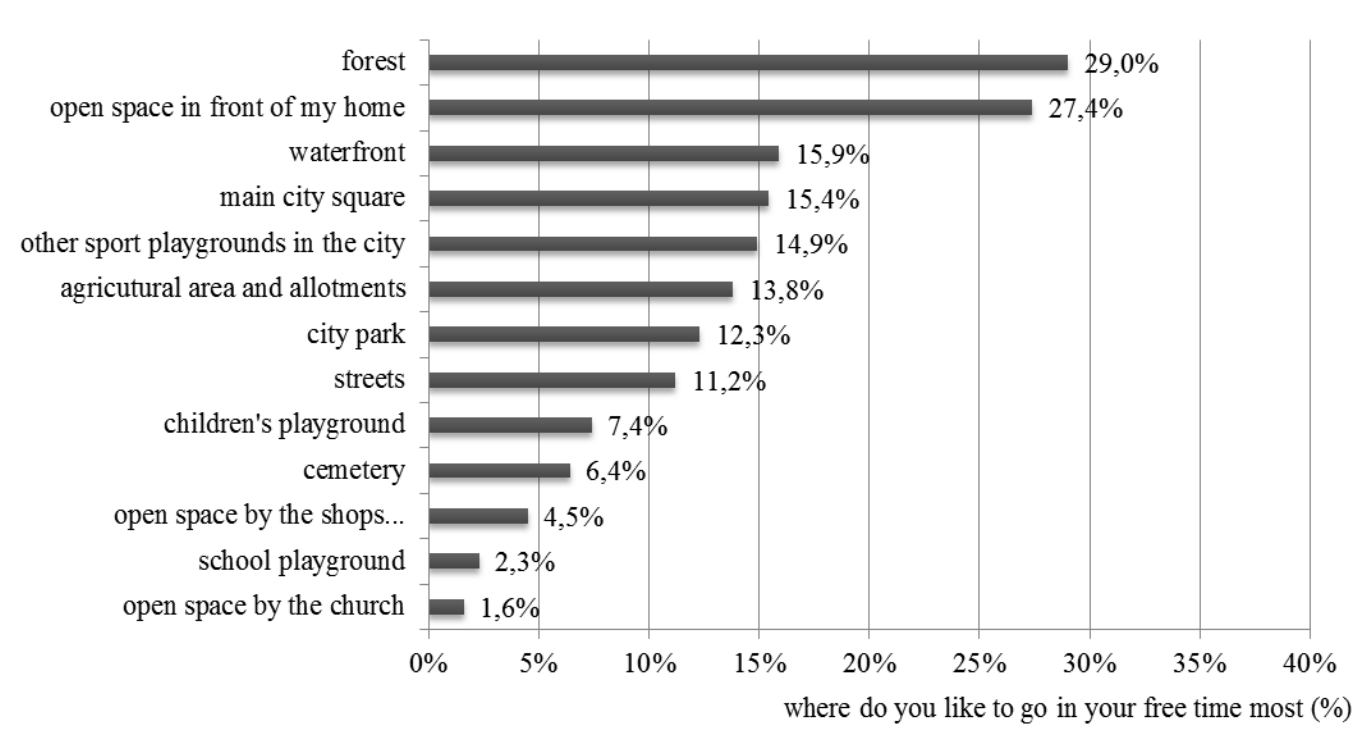

Figure 9: Answers to the question where people like to spend their free time (source: Vertelj Nared, 2014).

City parks, town squares, or even children's playgrounds as the POS that contribute greatly to a place's urbanity are not among the favourite places in the small cities under study. People nevertheless see them as important components of the city. On the question of what spaces should not be lacking in any city, the ones that topped the list were not those most 
frequently used by a majority of residents, if we exclude sidewalks. On the contrary, respondents felt that every city should contain urban open areas such as parks, children's and sport playgrounds, sidewalks and bicycle paths, water and waterfront, squares, etc. (Figure $10)$.

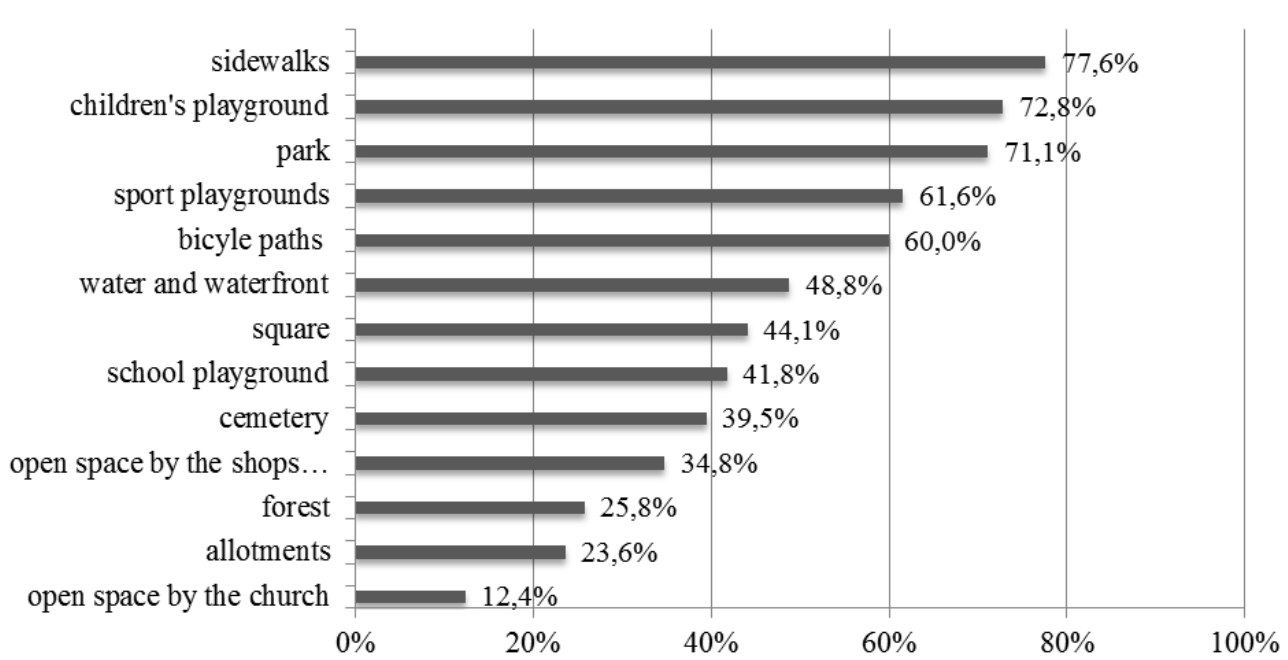

Figure 10: Answers on what spaces should not be lacking in any city (source: Vertelj Nared, 2014).

\section{Summary of results}

Physical analysis of POS shows that cities are variously endowed with POS. Not all types of POS are present in all cities. The biggest differences between cities were in the presence or absence parks, public children's playgrounds, or squares reserved for pedestrians. The amenities offered by these types of POS influence how frequently they are used. It was found that people in cities with a well-designed and well-maintained park use it more frequently than in cities with no such park (Vertelj Nared, 2014).

Furthermore, the survey illustrated two important facts:

- Firstly, inhabitants most often use POS in going about their daily business. Besides their own garden (open space at their home), they most frequently use "functional" POS, e.g. streets, in going about their daily business. They use streets no matter how pleasant they are or how satisfied they are with the arrangements, simply because there is no alternative.

- Secondly, some types of POS are of great importance for the quality of life and urban development, even if most people do not use them very frequently. Respondents find, for example, children's playground, parks, and sport playgrounds, beside sidewalks and bicycle paths, very important for any city, however often they personally use them. These types of POS are therefore important for the urban development of any city.

Both facts confirm the importance of designing pleasant and diverse POS that contributes to the quality of life in cities. Special attention should therefore be directed towards planning and designing POS that is used daily (e.g. streets) or POS intended for specific user groups (e.g. children's playground). For urban development, diverse POS that enhances the everyday quality of life is of great importance.

These findings invite the conclusion that for everyday life and the quality of life in small cities, public open space of various types (both green areas and civic space) is very important. We stress that well-maintained POS is of particular importance for both everyday life and for the quality of life in urban areas. 


\section{Discussion}

Improving everyday life is still the main aim of spatial planning at the national and local levels. By improving the physical environment, including POS, we improve conditions for enhancing the quality of life and well-being in urban areas. The question is how local spatial planning contributes to improving POS in small cities.

Our findings on POS in small Slovenian cities confirm findings that "the spotlight must be on everyday situations and spaces where everyday life takes" (Gehl, 2006: 51). It is recognized that an active life includes physical activities as part of daily routines (Kellett \& Rofe, 2009: 15). Municipal authorities and spatial planners must therefore take our daily activities into consideration in their planning. It is particularly important to establish highquality spatial arrangements, since they create the conditions for the quality of life and influence our well-being. POS in cities should therefore permit the safe and enjoyable everyday use of links between different parts of the city. Areas of POS should be available for everyday use and for the benefit of all residents. For this purpose, cities should be endowed with elements that enhance sustainable urban mobility (e.g. pavements, bicycle paths, pedestrian areas without motorised traffic, public transport). These arrangements can encourage casual contacts among residents going about their daily business and can increase the quality of life.

Legislation, guidelines, spatial planning policy documents, and standards have a significant impact on the provision and design of urban open space. On the other hand, problems arise in the implementation of rules, which are mainly normative. As research since the 1970s has shown, the problem of standards and norms is primarily that they do not necessarily take real physical conditions, or the needs of people or different user groups into account (Byrne \& Sipe, 2010). Those who criticize "national standards" point out that they are conceived as "one rule for all" that cannot give due consideration to the particularities of a given space (Byrne \& Sipe, 2010: 20, 21). CABE (2005: 50) points out that national standards must be applied with caution. They can be a good starting point, but they are most effective when they are set in accordance with local social needs and space (ibid.). If standards are to be enforced, they should not be referred to the national level but implemented locally.

The provision of high-quality, well-maintained, and varied POS is therefore best specified at the local level, taking into account the spatial characteristic, needs, and municipality vision for development and capabilities. It is important to integrate the development of different areas with quality requirements at both the strategic implementational levels.

The strategic sections of municipal spatial plans in Slovenia provide the basis for the urban area development, including the requirements or guidelines for the quality, size and location of POS.

Strategic guidelines include: (1) general guidelines for urban development, including the maintenance and development of open space (e.g. "quality of life in the city can be enhanced by providing and regulating public spaces and urban equipment"), or (2) practical guidelines for establishing new POS arrangements (e.g. "the area must be designed as a green axis of the city with pathways, green spaces, and places to sit and rest and other urban amenities").

At the implementational level, the quality of POS is regulated by land use and detailed rules. Combining the results of a survey on what areas respondents use most frequently with the land uses in ten selected cities shows that residents most frequently use POS in central, mixed land use areas and residential areas (Vertelj Nared, 2014). The most frequently used areas of POS are not those defined as "green land uses" as expected, but are hidden in other land uses. It would therefore be appropriate at least some of the requirements for high-quality POS to address different land uses and not only green areas or the provision of green areas in residential areas. 
The results of this study are of special importance because they reveal the responsibility of spatial planning practices. It was found that in designing spatial arrangements we do not only construct space but, more importantly, enable its use (Vertelj Nared, 2014) and influence the quality of life in cities. Ultimately, participatory collaborative planning (Kos, 2010) is therefore stressed as one of the ways of ensuring that open space is of high quality. It provides for the inclusion of various stakeholders in the planning process, but at the same time a clear division of roles between professionals and the public. Public opinion should be sounded out and public integrated at a reasonably early stage in the planning process. The best possible solutions must be put forward. The aim of the process is to ensure better conditions for the quality of life in cities.

\section{Conclusion}

Prior to the research on the subject conducted in the context of a doctoral thesis (Vertelj Nared, 2014) from where the findings discussed in the article are taken, no comprehensive investigation of on POS in relation to the quality of life in small Slovenian cities had been undertaken. The research stresses the importance of planning and designing diverse and wellmaintained POS (both green areas and civic space) that contribute to the quality of life in cities. Physical analysis and survey findings showing that residents use POS most frequently when going about their everyday business point to the need to design high-quality space for everyday activities.

The diversity of spatial arrangements opens up the possibility of multiple uses of POS. The more diverse the arrangements, functions, and activities of open public space are, the greater opportunities there will be for a variety of uses and activities in the city. The role of POS in balanced urban development is therefore to support improvements in the quality of life, to enable social contact, and to maintain or re-establish cultural diversity and local identity.

\section{Acknowledgments}

This article is based on research that was carried out for a doctoral dissertation, which was supported by the European Social Fund. The authors would like to thank assoc.prof. Drago Kos, Ph.D., co-advisor of the dissertation, and M.Sc. Maja Simoneti, research mentor at LUZ, d.d.

\section{References}

Beck, H. (2009) Linking the quality of public spaces to quality of life. Journal of Place Management and Development, 2(3), pp. 240-248. DOI: 10.1108/17538330911013933

Bell, D. \& Jayne, M. (eds.) (2006) Small Cities: Urban experience beyond the metropolis. New York, Abingdon, Routledge.

Bratina Jurkovič, N. (2014) Perception, experience and the use of public urban spaces by residents of urban neighbourhoods. Urbani izziv, 25(1), pp. 107-125. DOI: 10.5379/urbani-izziv-en-2014-25-01-003

Byrne, J., Sipe, N. (2010) Green and open space planning for urban consolidation - A review of the literature and best practice. Urban Research Program. Issues Paper 11. Brisbane, Griffith University, p. 60.

CABE (2005) Start with the Park. Creating sustainable urban green spaces in areas of housing growth and renewal. Commission for Architecture and Built Environment. UK. Available at:

http://webarchive.nationalarchives.gov.uk/20110118095356/http:/www.cabe.org.uk/files/s tartwith-the-park.pdf (accessed 15 May 2013) 
Carr, S., Francis, M., Rivlin, L. G. \& Stone, A. M. (1992) Public Space. Cambridge, Cambridge University Press.

Cerar, A. (2014) From reaction to initiative: Potentials of contributive participation. Urbani izziv, 25(1), pp. 93-106. DOI: 10.5379/urbani-izziv-en-2014-25-01-002

Dinnie, E., Brown, K. M. \& Morris, S. (2013) Community, cooperation and conflict: Negotiating the social well-being benefits of urban greenspace experiences. Landscape and Urban Planning, 112, pp. 1-9. DOI: http://dx.doi.org/10.1016/j.landurbplan.2012.12.012

ESPON (2006) ESPON 1.4.1. Small and Medium Size Towns (SMESTO). Available at: http://www.espon.eu/export/sites/default/Documents/Projects/ESPON2006Projects/Studie sScientificSupportProjects/SmallMediumCities/fr-1.4.1_revised-full.pdf (accessed 10 Jan. 2011)

European Green City Index (2010) Assesing the environmental impact of Europe's major cities. Available at: http://www.siemens.com/press/en/events/corporate/2009-12Cop15.php in http://www.commoncurrent.com/notes/2009/12/european-green-city-indexrele.html (accessed 12 Jan. 2011)

European Landscape Convention (2003) Zakon o ratifikaciji Evropske konvencije o krajini. Ur. 1. RS 74/2003. Ljubljana.

Frick, D. \& Hoefert, H. W. (eds.) (1986) Quality of urban life: Social, Psychological and Physical Conditions. Berlin and New York, Walter de Gruyter.

Fromm, E. (2002) Človek za sebe: Psihološka raziskava etike / Man for himself: An inquiry into the Psychology of Ethics. Ljubljana, Amalietti \& Amalietti.

Gehl, J. (2006) Life between buildings, Using Public Space. Washington, Covelo, London, The Danish Architectural Press.

European Commission (2013) Green Infrastructure (GI) - Enhancing Europe's Natural Capital . Available at: http://eur-lex.europa.eu/legalcontent/EN/TXT/?uri=celex:52013DC0249 (accessed 5 Aug. 2015)

Healthy Open Spaces (2010) Available at: http://www.rph.org.nz/content/e12cc009-f06c4650-99da-ecb9c81de1f4.cmr (accessed 10 May 2013)

Jackson, L. E. (2003) The relationship of urban design to human health and condition. Landscape and Urban Planning, 64(4), pp. 191-200. DOI: 10.1016/S01692046(02)00230-X

Kellet, J., Rofe, M. W. (2009) Creating Active Communities: How Can Open and Public Spaces in Urban and Suburban Environment Support Active Living? Institute for Sustainable Systems and Technologies, University of South Australia for the South Australiam Active Living Coalition. Available at: http://saactivelivingcoalition.com.au/wp-content/uploads/2012/05/Creating-ActiveCommunities-FULL-REPORT.pdf (accessed 15 May 2013)

Kos, D. (2007) Neurbana nacija. In: Čerpes, I. \& Dešman, M. (eds.): O urbanizmu, Kaj se dogaja s sodobnim mestom? pp. 137-163. Ljubljana, Krtina.

Kos, D. (2008) Polivalentnost mestnih prostorov. AB, Arhitektov bilten, 38(177-178), pp. 6061. URN:NBN:SI:DOC-H9CR2BVS Available at: http://www.dlib.si (accessed 13 Jul. 2015)

Kos, D. (2010) Prostorsko urejanje med »stroko« in »piarom«. Teorija in praksa, 47(2-3), pp. 413-434. Available at: http://dk.fdv.uni-lj.si/db/pdfs/tip20102-3_Kos1.pdf (accessed 10 Aug. 2015)

Leipzig charter on sustainable European cities (2007) Available at: http://ec.europa.eu/regional_policy/archive/themes/urban/leipzig_charter.pdf (accessed 10 Aug. 2015) 
Low, S. \& Smith, N. (2006) The Politics of Public Space. New York, London, Routledge, Taylor \& Francis Group.

Luttik, J. (2000) The value of trees, water and open space as reflected by house prices in the Netherlands. Landscape and Urban Planning, 48, pp. 161-167. DOI: 10.1016/S01692046(00)00039-6

Maas, J., Verheij, R. A., Groenewegen, P. P., de Vries, S. \& Spreeuwenberg, P. (2006) Green space, urbanity and health: how strong is the relation? Epidemiol Community Health, 60, pp. 587-592. DOI: $10.1136 /$ jech.2005.043125

Madanipour, A. (2012) Reclaiming public space from rigid orders and narrow interests. Available at: http://www.uirs.si/pub/humancities2012.pdf (accessed 10 Apr. 2013)

Mercer (2010) Defining »Quality of life«. Available at: http://www.mercer.com/referencecontent.htm?idContent=1380465 (accessed 2 Feb. 2011)

Mostafavi, M. \& Doherty, G. (eds.) (2010) Ecological Urbanism. Baden, Lars Müller Publishers.

Mumford, L. (1969) Mesto v zgodovini /The City in history. Ljubljana, Državna založba Slovenije.

Paquet, C., Orschulok, T. P., Coffee, N. T., Howard, N. J., Hugo, G., Taylor A. W., Adams, R. J. \& Daniel, M. (2013) Are accessibility and characteristics of public spaces associated with a better cardiometabolic health? Landscape and Urban Planning, 118, pp. 70-78. DOI: 10.1016/j.landurbplan.2012.11.011

Pavlin, B., Milenkovič, A., Klasinc, S., et al. (2003). Mestna naselja v Republiki Sloveniji. Ljubljana: Statistični urad Republike Slovenije. Available at: www.stat.si/doc/pub/mestna_naselja_slo_03.pdf (accessed 6 Apr. 2015)

Planning and Open Space (2008) Planning Advice Note 65. The Scottish Government. Available at: http://www.scotland.gov.uk/Resource/Doc/225179/0060935.pdf (accessed 10. 5. 2013)

Richardson, E. A. \& Mitchell, R. (2010) Gender differences in relationship between urban green space and health in the United Kingdom. Social Science \& Medicine, 71, pp. 568575. DOI: 10.1016/j.socscimed.2010.04.015

Quality of life in Europe (2004) First European Quality of Life Survey 2003. Available at: http://www.eurofound.europa.eu/pubdocs/2004/105/en/1/ef04105en.pdf (accessed 17. 7. 2010)

Sendi, R. (2013) The low housing standard in Slovenia: Low purchasing power as an eternal excuse. Urbani izziv, 24(1), pp. 107-124. DOI: 10.5379/urbani-izziv-en-2013-24-01-002

SDSP (2004) Spatial Development Strategy of Slovenia. Ur. 1. RS 76/2004. Ljubljana.

SOS (2004) Spatial order od Slovenia. Ur. 1. RS 122/2004. Ljubljana.

Stiles, R. (2009) Urban spaces - enhancing the attractiveness and quality of the urban environment. Project UrbSpace. Vienna University of Technology. Available at : http://www.central2013.eu/fileadmin/user_upload/Downloads/outputlib/Urbspace_3.1.1._ Analyses_of_common_problems.pdf (accessed 10 Oct. 2010)

Sugiyama, T. \& Ward Thompson, C. (2007) Older people's health, outdoor activity and supportiveness of neighbourhood environments. Landscape and Urban Planning, 83, pp. 168-175. DOI: 10.1016/j.landurbplan.2007.04.002

SURS (2010) Office for National Statistics / SI-Stat podatkovni portal. Available at: http://www.stat.si/ (accessed 15 Dec. 2010)

SURS (2013) Office for National Statistics / SI-Stat podatkovni portal. Available at: http://www.stat.si/ (accessed 8 Jul. 2013)

Thematic strategy on urban environment (2006) Available at: http://eurlex.europa.eu/LexUriServ/LexUriServ.do?uri=OJ:C:2006:306E:0182:0188:SL:PDF (accessed 2 Oct. 2010) 
Urban 21 Conference (2000) Available at: http://www.hic-al.org/anterior/cartaseng_3.html (accessed 9. Oct. 2011)

Urban Audit (2011) How cities rank. Available at: http://www.urbanaudit.org/ (accessed 18 Jun. 2011)

Urban Open and Green Space Typology (2002) Available at: http://www.communities.gov.uk/documents/communities/pdf/131015.pdf (accessed 5 Aug. 2011)

Vertelj Nared, P. (2014) Vloga javnega prostora kot podpora urbanemu razvoju na primeru majhnih mest $v$ Sloveniji / The role of Public Open Space as Urban Development Support in Small Slovenian Cities Case Study. Doctoral thesis. Ljubljana, University of Ljubljana, Faculty of Civil and Geodetic Engineering.

Ward Thompson, C. \& Aspinall, P. (2011) Natural environments and their impact on activity, health and quality of life. Applied Psychology: Health and Well-Being, 3(3), pp. 230-260. DOI: $10.1111 /$ j.1758-0854.2011.01053.x

Ward Thompson, C., Roe, J., Aspinall, P., Mitchell, R., Clow, A. \& Miller, D. (2012) More green space is linked to less stress in deprived communities: Evidence from salivary cortisol patterns. Landscape and Urban Planning, 105, pp. 221-229. DOI: 10.1016/j.landurbplan.2011.12.015

Zavodnik Lamovšek, A., Drobne, S., Žaucer, T. (2008) Small and medium-size towns as the basis of polycentric urban development / Majhna in srednje velika mesta kot ogrodje policentričnega urbanega razvoja. Geodetski vestnik. 52(2), pp. 290-312.

ZGO-1 (2002) Zakon o graditvi objektov, Ur. l. RS 110/2002, Ljubljana. 